\title{
THE ROLE OF ISLAMIC RELIGIOUS EDUCATION TEACHERS IN ACTUALIZING TOLERANCE ATTITUDES TO STUDENTS
}

\author{
Fahmi Eko Saputro \\ Institut Agama Islam Negeri Salatiga, Jawa Tengah, Indonesia \\ Email: fahmiskripsi2@gmail.com
}

DOI: 10.35445/alishlah.v12.i2.214

Accepted: July $28^{\text {th }}, 2020$. Approved: October $28^{\text {th }}, 2020$

Published: December $30^{\text {th }}, 2020$

\begin{abstract}
The purpose of this study is to find out the role of the teacher of Islamic religious education in actualizing the tolerance attitude to the students and how the tolerance of the students. This research uses descriptive qualitative method with data collection such as observation, interviews, and documentation. The results of this study are, First, the role of teachers in instilling an attitude of tolerance towards students, namely acting as an informator, motivator, director, facilitator and evaluator that aligns with tolerance material. Second, the tolerance of students in this case, namely the attitude of tolerance towards friends, the attitude of tolerance towards teachers, the attitude of tolerance towards the school community and the attitude of tolerance towards parents.
\end{abstract}

Keywords : Tolerance, Attitude, Islamic Religious Education Teacher

\section{PERAN GURU PAI DALAM MENGAKTUALISASIKAN SIKAP TOLERANSI KEPADA PESERTA DIDIK}

\begin{abstract}
Abstrak
Tujuan dari penelitian ini yaitu untuk mengetahui bagaimana peran guru Pendidikan Agama Islam dalam mengaktualisasikan sikap toleransi pada peserta didik dan bagaimana sikap toleransi peserta didiknya. Metode yang digunakan pada penelitian ini adalah kualitatif deskriptif dengan pengumpulan data seperti observasi, wawancara, dan dokumentasi. Dari hasil penelitian diketahui bahwa peran guru dalam menanamkan sikap toleransi terhadap peserta didik yakni bertindak sebagai informator, motivator, pengarah, fasilitator dan evaluator yang menyelaraskan dengan materi toleransi. Kedua: Sikap toleransi peserta didik dalam hal ini yakni sikap toleransi terhadap teman, sikap toleransi terhadap guru,sikap toleransi terhadap masyarakat sekolah dan sikap toleransi terhadap orang tua.
\end{abstract}


Kata Kunci : Toleransi, Sikap, Guru Pendidikan Agama Islam

\section{PENDAHULUAN}

Pendidikan adalah hal yang penting dalam kehidupan manusia karena dengan pendidikan akan melahirkan manusia yang martabat. Maka dari itu pendidikan harus menyesuaikan dengan perkembangan zaman (Gunawan, 2014: 1). Pendidikan Pendidikan Agama Islam merupakan suatu proses mendidik, memelihara, membentuk, dan memberikan latihan mengenai akhlak dan kecerdasan berpikir baik secara formal maupun informal yang berdasar pada ajaran-ajaran Islam. Pendidikan Agama Islam diartikan sebagai mental dan fisik yang menghasilkan manusia yang berbudaya tinggi untuk melaksanakan tugas kewajiban dan tanggung jawabnya dalam masyarakat selaku hamba Allah. Pendidikan Pendidikan Agama Islam akan menumbuhkan personalitas yang baik dan menanamkan tanggung jawab terhadap manusia. Sebagaimana firman Allah dalam QS Ali Imran/3:19.

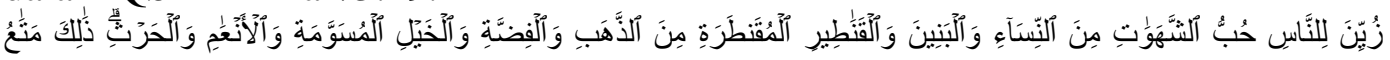

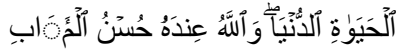

Artinya: Sesungguhnya agama (yang diridhai) disisi Allah hanyalah Islam. tiada berselisih orang-orang yang Telah diberi Al Kitab kecuali sesudah datang pengetahuan kepada mereka, Karena kedengkian (yang ada) di antara mereka. barangsiapa yang kafir terhadap ayat-ayat Allah Maka Sesungguhnya Allah sangat cepat hisab-Nya (Q.S. Ali Imran'/3:19), (Hasbi Ashiddiqi. Dkk, 1971: 78).

Oleh karena itu, selaku umat muslim yang baik sepatutnya menaati ajaran Islam dan menjaga agar rahmat Allah tetap berada pada dirinya, memahami, menghayati, dan mengamalkan ajarannya sesuai dengan pendidikan agama islam yang Islamiyah. Pembinaan pendidikan agama islam di sekolah harus dilakukan secara teratur dan terarah agar peserta didik agar dapat mengembangkan dan menerapkannya dalam kehidupan sehari-hari. Untuk mencapai tujuan itu tentu tidak lepas dari beberapa faktor penunjang yang tersedia dan terlaksana dengan baik, seperti tenaga pengajar yang baik serta faktor lain yang berpengaruh terhadap proses dari secara keseluruhan. Untuk itu, kesuksesan pembelajaran tidak lepas dari peran guru Pendidikan Agama Islam yang profesional. Guru adalah semua orang yang berwenang dan bertanggung jawab terhadap pendidikan peserta didik, baik secara individual maupun klasikal, baik di sekolah maupun di luar sekolah (Akmal Hawi, 2013: 9).

Di era globalisasi yang semakin maju seperti sekarang ini, banyak memberikan pengaruh positif maupun negatif bagi masyarakat. Jika seseorang tidak pandai dalam memanfaatkan kemajuan teknologi, maka seseorang akan terperosok dalam kehancuran, sebaliknya jika seseorang pandai memanfaatkannya maka seseorang itu akan menjadi manusia yang sukses baik di dunia maupun di 
akhirat. Namun kenyataannya akhir-akhir ini hal yang sering dijumpai yaitu kemerosotan sikap toleransi antara sesama manusia. Kemerosotan tersebut ditandai dengan banyaknya informasi negatif yang didapatkan, baik yang ada di lingkungan sekitar maupun dilihat dari media sosial seperti perkelahian antar suku karena adanya perbedaan budaya, perkelahian antar umat beragama karena perbedaan akidah, perselisihan antar sesama agama karena perbedaan mazhab, dan perkelahian antar pelajar karena egoisme. Hal itu terjadi karena kurangnya penerapan sikap toleransi antar sesama manusia.

Sehubungan dengan masalah tersebut, hal yang paling penting ditanamkan oleh guru kepada peserta didik adalah penanaman pemahaman sikap toleransi dan proses penerapan sikap toleransi di usia dini. Hibana S. Rahman mengatakan bahwa pendidikan anak usia dini memegang peran penting dalam menentukan sejarah perkembangan anak selanjutnya (Hibana S. Rahman, 2002: 4). Nilai-nilai sikap toleransi yang ditanamkan oleh guru akan membawa pengaruh terhadap kepribadian manusia yang tampak dalam sikap lahiriyah. Sebagai guru Pendidikan Agama Islam, sudah seharusnya menjaga peserta didik dari pengaruh negatif yang timbul akibat dari era globalisasi yang semakin maju. Oleh sebab itu, dikalangan siswa juga penting dikembangkan nilai-nilai toleransi, agar peserta didik dapat menghormati dan menerima perbedaan orang lain, dapat menghargai kebebasan fundamental siswa lainnya, tanpa perendahan diri, apalagi menghilangkan hak-hak individu dirinya.

Terkait dengan masalah pendidikan dari pengembangan toleransi yang pernah diteliti banyak sekali diantara: Nur Said (2016) berjudul "Pendidikan Toleransi Beragama untuk Humanisme Islam di Indonesia” yang menjelaskan tentang respon atas gejolak bernuansa agama beberapa tahun terakhir di Indonesia. Institusi Pendidikan Islam memiliki tanggung jawab atas historisitas Islam aktual untuk menjadi bangsa toleran atau intoleran. Imam Tholkhah (2013) berjudul "Pendidikan Toleransi Keagamaan: Studi Kasus SMA Muhammadiyah Kupang Nusa tenggara Timur" yang menjelaskan tentang studi kasus pengembangan budaya toleransi keagaaman yang berlangsung yakni diantara mencakup pengembangan budaya toleransi sebagai upaya menjalankan dakwah secara inklusif. Ni Nyoman Ayu Suciartini (2017) berjudul "Urgensi Pendidikan Toleransi Dalam Wajah Pembelajaran Sebagai Upaya Meningkatkan Kualitas Pendidikan" yang menjelaskan tentang peran penting pendidik dalam rangka menjadi ujung tombak dalam rangka menyemai nilai kebaikan karakter melalui pendidikan toleransi ditengah kondisi multikulturalisme. Rifqi Fachrian Muhammad (2017) berjudul "Toleransi Antar Umat Beragama Dalam Alquran" yang berisi tentang konsep-konsep toleransi yang terdapat dalam Alquran yang 
disandarkan pada pendekatan tafsir guna memahami secara jelas makna serta batasan-batasan yang ada di dalamnya.

Terkait dengan penjelasan dari observasi terdahulu di atas penulis memilih MI Asas Islam Kalibening Salatiga sebagai objek penelitian. Adapun yang menjadi pembeda dari penelitian sebelumnya yang telah diutarakan di atas antara lain adalah peranan guru Pendidikan Agama Islam dalam menanamkan sikap toleransi terhadap peserta didik dan penggambaran sikap toleransi yang dimiliki peserta didik. Penelitian ini penting dilakukan sebagai upaya penanaman nilai toleransi beragama sejak usia dini. Sehingga guru Pendidikan Agama Islam mampu memberikan langkah yang tepat dalam penanaman nilai toleransi dan setiap peserta didik mengetahui bentuk-bentuk toleransi.

\section{METODE PENELITIAN}

Metode penelitian yang digunakan dalam penelitian ini yaitu metode penelitian kualitatif. Metode penelitian kualitatif dengan menggunakan jenis penelitian lapangan (Field Research). Metode penelitian kualitatif berguna untuk memperoleh data yang mendalam dan mengandung makna sesuai yang terjadi di lapangan. Oleh sebab itu, dalam penelitian kualitatif tidak menekankan pada generalisasi, akan tetapi lebih menekankan pada makna yang terkandung di dalamnya (Sugiyono, 2013: 15). Langkah utama dalam penelitian dapat dilihat dari teknik pengumpulan data yang dilakukan. Maka dari itu, pengempulan data yang dilakukan oleh penulis yakni observasi (pengamatan), interview (wawancara), dan dokumentasi.

Penelitian ini dilakukan di MI Asas Islam Kalibening Salatiga. Adapun teknik dalam pengambilan data pada penelitian ini dengan melakukan wawancara kepada guru Pendidikan Agama Islam dan peserta didik MI Asas Islam Kalibening Salatiga. Peneliti juga melakukan observasi langsung pada peserta didik terkait sikap toleransi peserta didik. Dalam penelitian ini, peneliti juga melakukan triagulasi data dengan melakukan cross check data hasil wawancara, observasi dan dokumentasi sehingga data yang diperoleh lebih akurat.

\section{HASIL PENELITIAN DAN PEMBAHASAN}

\section{Peran Guru Pendidikan Agama Islam dalam Penanaman Nilai Toleransi}

Dari hasil penelitian diketahui bahwa guru senantiasa mendapat pendampingan baik secara praktek maupun teori. Hal ini juga menjadi sangat penting, mengingat kualitas yang dimiliki akan mempengaruhi siswa yang menjadi bagian dari madrasah ini. Terkait dengan hal ini setidaknya 2 hingga 3 bulan sekali ada pelatihan serta pembinaan secara mental sehingga guru secara langsung ikut andil dan ambil bagian dari pendidikan. Hingga kini pihak madrasah terus mengupayakan bagaimana strategi dan cara terbaik dalam rangka 
mengoptimalkan fungsi dan kinerja guru yang secara idealnya telah dijelaskan oleh banyak ahli pendidikan, baik itu pembinaan secara praktek maupun teori. Pembinaan secara lahiriah dan batiniah merupakan ikhtiar pihak madrasah untuk memupuk fungsi dalam penanaman pendidikan toleransi dan menghargai sesama.

Beberapa yang dilakukan oleh guru akidah di MI Asas Islam Kalibening Salatiga dalam melaksanakan perannya yaitu bertindak sebagai informator, motivator, pengarah, fasilitator dan evaluator. Peranan tersebut kemudian direalisasikan dalam proses pembelajaran pendidikan agama islam tepatnya pada materi tentang toleransi. Untuk melihat kesesuaian informasi ini, dapat dilihat dari hasil wawancara sebagai berikut:

a. Sebagai informator

"Cara yang saya lakukan dalam melaksanakan peran saya yaitu sebagai informator dengan mengajak peserta didik untuk melihat objek pengkajian tentang sikap toleransi, memberikan informasi ilmu pengetahuan sesuai dengan materi ajar sikap toleransi yang baik, menyampaikan tujuan pembelajaran sikap toleransi sesuai dengan kurikulum yang berlaku, menyampaikan materi toleransi dengan bahasa yang lugas, mengerti kebutuhan peserta didik dalam belajar sikap toleransi”.

Pendapat ini, sejalan dengan konsep yang ditawarkan Syaiful Bahri Djamarah yang dikutip oleh Rizka Nurrahmawati tentang peran guru sebagai informator. Guru harus mampu mentransferkan informasi-informasi sesuai dengan mata pelajaran yang selaras perkembangan ilmu pengetahuan dan teknologi. Efektifnya informasi dari guru adalah guru yang mengerti akan kebutuhan peserta didik serta penyampaian yang dapat menarik motivasi belajarnya (Rizka Nurrahmawati, 2016: 969).

b. Sebagai Motivator

"Cara yang saya lakukan dalam melaksanakan peranan guru sebagai motivator yaitu mendorong peserta didik agar bergairah dan aktif dalam belajar toleransi, menganalisa motif-motif yang membuat peserta didik malas belajar toleransi kemudian mencarikan solusinya, memacu sedemikian rupa agar mereka mampu belajar sikap toleransi secara mandiri, merangsang potensi peserta didik dalam mengembangkan pengetahuan dan wawasannya tentang pentingnya sikap toleransi".

Pendapat di atas selaras dengan konsep peran guru sebagai motivator yang ditawarkan Elly Manizar dalam jurnalnya. Ada beberapa hal yang perlu diaktualisasikan oleh guru dalam meningkatkan motivasi belajar peserta didik yaitu bersikap terbuka terhadap peserta didik, membantu peserta didik supaya mudah memahami pembelajaran secara opimal, mewujudkan hubungan emosional dengan penuh gairah dalam interaksi pembelajaran, menumbuhkan minat belajar 
peserta didik dengan menekankan sikap aktif dan subjektif (Elly Manizar, 2015: 179).

\section{c. Sebagai Pengarah}

"Sebagai pengarah senantiasa mengarahkan peserta untuk selalu bersikap toleransi dengan sesama, mengarahkan peserta didik untuk belajar sikap toleransi dengan aktif, memberikan pengetahuan yang benar kepada peserta didik tentang sikap toleransi, mengarahkan peserta didik untuk mencapai tujuan pembelajaran sikap toleransi, mengarahkan pembelajaran toleransi kepada peserta didik agar sesuai dengan kurikulum yang berlaku, memberikan petunjuk tentang cara belajar toleransi dengan efektif"'.

Informasi yang dipaparkan informan ternyata sejalan dengan konsep peran guru sebagai pengarah yang ditawarkan oleh Sitti Arafah dalam jurnalnya. Peran guru sebagai pengarah sering juga disebut dengan kata director yang senantiasa paham akan makna kepimpinanan. Guru sebagai pengarah agar memiliki jiwa kepemimpinan yang menonjol dalam menjalankan proses pembelajaran. Jiwa kepemimpinan maksudnya adalah guru dituntut untuk mampu mengarahkan serta membimbing kegiatan peserta didik sesuai dengan tujuan yang hendak dicapai (Sitti Arafah, 2017: 53).

d. Sebagai Fasilitator

"Dalam mengaktualisasikan peranan sebagai fasilitator yaitu menyiapkan materi toleransi dengan baik, pelajaran disisipi dengan permainan agar peserta didik tidak jenuh dalam belajar sikap toleransi, menyiapkan media elektronik dalam proses pembelajran toleransi, menyiapkan card sort sesuai dengan materi ajar sikap toleransi, dan memfasilitasi apapun yang menjadi kebutuhan pembelajaran sikap toleransi".

Pendapat di atas sejalan dengan konsep yang ditawarkan Denizlaiha dalam jurnalnya sebagai berikut: berperan sebagai fasilitator, guru dalam hal ini akan memberikan fasilitasi atau kemudahan dalam proses pembelajaran, misalnya saja dengan menciptakan suasana kegiatan belajar yang sedemikian rupa, serasi dengan perkembangan anak sehingga interaksi pembelajaran akan berlangsung secara efektif dan efesien (Denizlaiha, 2020).

e. Sebagai Evaluator

"Dalam melaksanakan peranan sebagai evaluator saya melihat sikap toleransi peserta didik apakah sikap toleransi tersebut sesuai dengan apa yang dipelajari, memberikan nasihat apabila mendapatkan peserta didik yang tidak bersikap toleransi terhadap sesamanya, memberikan pertanyaan tentang sikap toleransi ketika selesai pembelajaran, melakukan perbandingan teori toleransi dengan fakta lapangan".

Pendapat di atas selaras dengan konsep yang ditawarkan oleh Nurhaidah dan M. Insya Musa dalam artikel jurnalnya. Peran guru sebagai evaluator merupakan hal yang penting untuk direalisasikan karena disinilah akan terlihat 
sejauh mana kesuksesan guru dalam mengajar dan sejauh mana peserta didik memahami apa yang dipelajarinya. Dalam proses evaluasi guru harus betul-betul objektif dalam memberikan penilaian karena dengan evaluasi tersebut guru dapat menjadikan sebagai bahan perbandingan untuk ke jenjang selanjutnya (Nurhaidah dan M. Insya Musa, 2016: 19).

Dari penjelasan diatas dapat dipahami bahwa ada beberapa poin yang dilakukan dalam melaksanakan peranannya sebagai guru Pendidikan Agama Islam khususnya pembinaan sikap toleransi terhadap peserta didik yaitu bertindak sebagai informator, motivator, pengarah, fasilitator, dan evaluator. Komponenkomponen tersebut diaplikasikan dalam proses pemahaman sikap toleransi melalui pembelajaran dan materi Pendidikan Agama Islam itu sendiri.

Peran guru dapat dilihat dari tiga fungsi utamanya yaitu perencana, pengelola dan penilai. Sehubungan dengan itu, hal yang berbeda diungkapkan oleh Syamsuddin Makamur terkait dengan peran dan fungsi guru yakni: sebagai pemelihara, pengembang, penerjemah, penerus, serta penyelenggara (Askhabul Kirom, 2017: 72). Dalam buku psikologi belajar dan mengajar yang ditulis oleh Dr. Oemar Malik menjelaskan bahwa peran guru dapat dikelompokkan sebagai berikut: Pertama: Sebagai pengajar, maksudnya adalah guru harus memberikan pelayanan kepada peserta didik di sekolah supaya peserta didik tersebut dapat sejalan dengan tujuan sekolahnya. Kedua: Sebagai pembimbing, pada fase ini guru senantiasa memberikan arahan kepada peserta didik sebagaimana yang dibutuhkan untuk melakukan penyesuaian secara maksiamal baik kepada lembaga, keluarga, maupun masyarakat (Oemar Malik, 2009: 33)

Beberapa pendapat di atas telah menjadi acuan penulis dalam melaksanakan penelitian. Sehingga penulis menemukan berbagai peranan guru Pendidikan Agama Islam pada saat melakukan observasi yakni: sebelum pembelajaran toleransi dimulai, guru terlebih dahulu menyampaikan tujuan pembelajaran, memberikan dorongan supaya peserta didik bergairah dalam proses pembelajaran, mengarahkan peserta didik untuk belajar toleransi dengan aktif, menyedikan media pembelajaran toleransi sesuai dengan standar kurikulum, setelah materi selesai guru memberikan evaluasi sebagai pengembangan hasil pembelajaran toleransi.

\section{Sikap Toleransi Peserta Didik di MI Asas Islam Kalibening Salatiga}

Menurut Kamus Besar Bahasa Indonesia, toleransi yang berasal dari kata "toleran" itu sendiri berarti bersifat atau bersikap menenggang (menghargai, membiarkan, membolehkan), pendirian (pendapat, pandangan, kepercayaan, kebiasaan, dan sebagainya) yang berbeda dan atau yang bertentangan dengan pendiriannya (Daryanto, 2008: 259). Toleransi juga berarti batas ukur untuk penambahan atau pengurangan yang masih diperbolehkan. Secara bahasa atau 
etimologi toleransi berasal dari bahasa Arab tasamuh yang artinya ampun, maaf dan lapang dada (Ahmad Warson Munawir, 2009: 1098). Dengan adanya sikap toleransi yang baik akan menyebabkan manusia itu menjadi pemaaf dan saling menghargai antar sesamanya. Sebagaimana di jelaskan oleh hadis riwayat AlBukhary pada kitab Iman sebagai berikut:

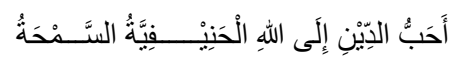

Agama yang paling di cintai disisi Allah adalah agama yang lurus dan toleransi (HR. Al- Bukhari). (Al-Bukhary, 1400 H: 156).

Sikap toleransi pada hakikatnya dapat dijadikan sebagai usaha membentengi diri dalam kehidupan yang semakin maju, terlebih bagi peserta didik yang masih menempuh pelajaran di sekolah. Sikap toleransi bagi peserta didik khususnya yang sudah menempuh pelajaran ditingkat MI, biasanya memiliki persepsi pemikiran yang bermacam-macam. Pemikiran tersebut dapat berupa egoisme, tidak menghargai pendapat teman, serta merasa dirinya paling benar. Maka dari itu, pemikiran-pemikiran yang negatif tersebut dibutuhkan sikap toleransi yang kuat demi mewujudkan keefektifan dalam berinteraksi.

Sebelum lebih jauh membahas tentang bagaimana sikap toleransi peserta didik Di MI Kalibening Salatiga, alangkah baiknya terlebih dahulu mengetahui dan memahami macam- macam sikap toleransi yang berpontensi terjadi di kalangan masyarakat sekolah. Ada beberapa macam sikap toleransi yang ditawarkan oleh Said Agil Al-Munawar dalam bukunya yang berjudul Fiqih Hubungan Antar Sesama sebagai berikut: (Said Agil Al-Munawar, 2003: 14-20).

Pertama, Sikap toleransi terhadap teman . Sikap tolernasi terhadap teman merupakan suatu perwujudan yang mencerminkan nilai-nilai toleransi yang positif. Agama Islam adalah agama yang membawa misi rahmatan lil alamin, maka dari itu di dalamnya selalu mengajarkan tentang bangaimana manusia mampu saling menghargai antar sesama teman sebayah. Sebagaimana contoh sikap toleransi terhdap teman sebayah seperti, senantiasa menyimak teman yang sedang berbicara, berbicara yang santun kepada teman, memiliki etika bergaul yang baik dengan teman, tidak membicarakan kejelekan teman, dan tidak mempermasalahkan latar belakan tradisi teman meskipun tradisi mereka tidak sama.

Kedua, Sikap toleransi terhadap guru. Guru merupakan orang yang mengajarkan dengan berbagai ilmu dan mendidik dengan sepenuh hati sehingga menjadi orang yang berbudi pekerti dan berguna bagi orang banyak. Oleh karena itu selaku peserta didik sepatutnya mencerminkan sikap toleransi yang baik terhadap guru. Toleransi terhadap guru dapat dilakukan dengan senantiasa mengucapkan salam ketika bertemu, bertutur kata dengan lemah lembut dengan 
guru, mematuhi perintah guru yang baik, menyimak dengan baik ketika guru menerangkan, tidak merasa marah ketika dinasehati oleh guru, dan meminta maaf ketika sedang berkata keliru terhadap guru.

Ketiga, Sikap toleransi terhadap orang tua. Orang tua merupakan orang yang paling berjasa dalam hidup seseorang. Dalam hubungan dengan orang tua seyogyanya seorang anak harus berbakti terhadap kedua orang tua. Berbakti terhadap orang tua merupakan perbuatan yang sangat terpuji di hadapan Allah swt. Salah satu bentuk bakti seorang anak terhadap orang tua yaitu dengan bersikap toleransi yang baik. Adapun contoh sikap toleransi yang baik kepada orang tua, seperti: senantiasa berbuat baik dan bersikap hormat baik dalam tingkah laku maupun tutur kata terhadap kedua orang tua, mengikuti keinginan dan saran orang tua selama keinginan dan saran-saran itu tidak melanggar ajaran agama, membantu kedua orang tua sesuai kemampuan, dan tidak berteriak-teriak ketika berbicara kepada orang tua.

Keempat, Sikap toleransi terhadap masyarakat sekolah. Masyarakat sekolah setiap individu yang berada dalam di lingkungan sekolah secara struktural. Masyarakat sekolah meliputi kepala sekolah, guru, staf, tenaga pembantu, dan peserta didik. Sikap toleransi terhadap masyarakat sekolah merupakan hal yang penting untuk ditanamkan pada peserta didik supaya lingkungan sekolah menjadi tempat yang nyaman dan kondusif. Adapun contoh sikap yang toleransi terhadap masyarakat sekolah seperti: senantiasa mematuhi tata tertib sekolah, saling menghormati dan menyayangi sesama pelajar, tidak berbicara kotor atau menyinggung perasaan orang lain, tidak membedakan teman sesuai ras, golongan ataupun agamanya.

Dari beberapa pendapat di atas telah menjadi bahan pertimbangan penulis dalam menggali informasi lebih dalam terkait sikap toleransi peserta didik di MI Asas Islam Kalibening Salatiga. Oleh karena itu, penulis telah melakukan wawancara langsung dengan guru Pendidikan Agama Islam di MI Asas Islam Kalibening Salatiga. Dengan maksud untuk mengetahui sikap toleransi peserta didik, maka penulis bertanya tentang bagaimana pandangannya tentang sikap toleransi peserta didik terhadap teman, guru, orang tua, dan masyarakat sekolah. Adapun hasil wawancara tersebut sebagai berikut:

"Toleransi peserta didik terhadap teman, guru, orang tua, dan masyarakat sekolah di MI Asas Islam Kalibening Salatiga cukup baik karena peserta didik dapat mencintai satu sama lain, menghindari perpecahan antara satu sama lain, hidup rukun dengan guru, tidak membantah perintah guru, bertutur kata yang sopan terhadap orang tua, menghindari perbedaan pendapat baik dengan teman, guru, orang tua, dan masyarakat sekolah". 
Dari hasil wawancara tersebut dapat dipahami bahwa sikap toleransi peserta didik cukup baik. Namun demikian, untuk menguatkan argumen tersebut penulis mencari lebih dalam lagi data-data yang dapat membuktikan ungkapan tersebut. ada beberapa acuan penulis dalam mengukur tingkat toleransi peserta didik MI Asas Islam Kalibening Salatiga yaitu:

Pertama, sikap toleransi terhadap temannya. Olehnya itu penulis mencoba untuk berinteraksi langsung dengan peserta didik dengan melakukan wawancara. Adapun hasil wawancara penulis ketika penulis bertanya tentang cara yang dilakukan dalam bersikap toleransi terhadap temannya sebagai berikut:

"Cara yang dilakukan bertoleransi terhadap teman yaitu, ketika berdiskusi memberikan hak penuh kepada teman agar menyampaikan pendapatnya sekalipun pendapatnya itu berbeda, tidak memilih-milih dalam berteman, selalu menjaga persahabatan dan menghindari perpecahan antara satu dengan yang lainnya".

Pendapat peserta didik tersebut dapat dianalisis bahwasanya dalam bersikap toleransi terhadap teman ada beberapa yang dilakukan yakni menghargai pendapat teman ketika berdiskusi, berteman dengan siapa saja tanpa melihat kekurangannya, menjaga keharmonisan dalam berteman serta menghindari hal-hal yang dapat memicu perpecahan. Dengan hal itu, membuktikan bahwa sikap toleransi peserta didik terhadap temannya tergolong baik.

Kedua, Sikap toleransi terhadap guru, Adapun hasil wawancara penulis terhadap narasumber pada saat penulis bertanya tantang cara yang dilakukan dalam bersikap toleransi terhadap gurunya yaitu:

"Cara yang saya lakukan dalam bersikap toleransi kepada guru yaitu dengan menghormati guru, membantu guru ketika membutuhkan bantuan, tidak berbicara ketika guru sedang menerangkan, selalu patuh terhadap perintah guru yang sifatnya positif, berbicara yang sopan dan santun ketika berhadapan dengan guru, tidak membantah nasehat yang di berikan guru”.

Pendapat dari narasumber tersebut merupakan perwujudan bahwa sikap toleransi peserta didik terhadap gurunya sudah berjalan dengan baik. Sebagaimana dijelaskan bahwa membantu kegiatan guru, hidup rukun dengan guru, bersikap sopan dan santun merupakan wujud yang terangkum dalam ruang linkup toleransi itu sediri.

Ketiga, sikap toleransi peserta didik terhadap orang tua, Adapun hasil wawancara dengan narasumber ketika penulis bertanya tentang cara yang dilakukan untuk bersikap toleransi terhadap orang tua yaitu :

"Cara yang saya lakukan dalam bersikap toleransi kepada orang tua yaitu menghargai perbedaan pendapat dengan orang tua, menerima nasehat kedua orang tuanya, tidak membantah perintah orang tua ketika disuruh, menghargai budaya dan tradisi keluarga, bertutur kata yang sopan kepada orang tuanya, dan selalu menghormati kedua orang tuanya". 
Dari hasil wawancara tersebut dapat dipahami bahwa ada beberapa cara yang dilakukan dalam bersikap toleransi kepada orang tua yakni, senantiasa menghargai keputusan orang tua meskipun tidak sejalan dengan keinginannya, menerima dengan senang hati nasihat dari orang tua meskipun nasihat tersebut di sampaikan dengan perkataan kasar, taat atas perintah orang tua selama sifatnya positif, sopan dan santun ketika berpapasan dengan orang tua. Wujud tersebut merupakan salah satu bukti bahwa sikap yang ditunjukkan oleh peserta didik tersebut tergolong memiliki sikap toleransi yang baik terhadap orang tua.

Keempat, sikap toleransi peserta didik terhadap masyarakat sekolah. Adapun hasil wawancara dengan narasumber ketika penulis bertanya tentang cara yang dilakukan dalam bersikap toleransi terhadap masyarakat sekolah:

"Cara yang saya lakukan dalam bersikap toleransi kepada masyarakat sekolah yaitu menghindari kata-kata yang dapat menyinggung perasaan orang lain, selalu menjaga keharmonisan sesama masyarakat sekolah, tidak bersikap sombong dengan masyarakat sekolah, menghargai adat kebiasaan yang muncul dari setiap masyarakat sekolah, saling bahu membahu agar mencapai perdamaian, saling mendukung satu sama lain, dan memaafkan ketika ada yang berbuat salah".

Dari pernyataan di atas dapat dipahami bahwa sikap toleransi kepada masyarakat sekolah tergolong baik, hal itu dibuktikan dengan pernyataan narasumber sebagaimana yang telah disebutkan dalam hasil wawancara.

Wawancara serta observasi (pengamatan) yang dilakukan penulis tentang sikap toleransi peserta didik MI Asas Islam Kalibening Salatiga tergolong sangat baik. Sebagaimana fakta yang penulis temukan di lapangan berkesesuaian dengan tingkah laku peserta didik. Sikap toleransi yang dimaksud disini adalah: 1) toleransi terhadap sesama teman, 2) toleransi terhadap guru-guru 3) toleransi terahadap orang tua, dan 4) toleransi terhadap sesama masyarakat sekolah. Olehnya itu, dengan hasil penelitian tersebut terkait dengan toleransi peserta didik di MI Asas Islam Kalibening Salatiga dapat dijadikan sebuah referensi demi terwujudnya kedamaian, ketentraman serta keseimbangan dalam berbangsa, beragama dan bernegara.

\section{SIMPULAN}

Berdasarkan penelitian dan dilanjutkan dengan penganalisaan serta penafsiran data yang telah penulis lakukan tentang peranan guru Pendidikan Agama Islam dalam mengaktualisasikan sikap toleransi pada peserta didik di MI Asas Islam Kalibening Salatiga, maka penulis dapat menyimpulkan bahwa Sikap toleransi peserta didik di MI Asas Islam Kalibening Salatiga cukup baik, sikap toleransi yang dimaksud yaitu sikap toleransi terhadap sesama temannya, sikap toleransi terhadap guru, sikap toleransi terhadap orang tua, sikap toleransi terhadap masyarakat sekolah. Sejalan dengan sikap toleransi peserta didik, tidak bisa dipungkiri bahwa tentu ada juga beberapa peserta didik yang belum memiliki 
sikap toleransi yang baik. Namun hal tersebut masih bisa diatasi oleh tenaga pendidik. Peranan guru Pendidikan Agama Islam menempati posisi penting dalam pendidikan dan memberikan kontribusi yang tinggi untuk peningkatan hasil belajar peserta didik, serta memiliki peranan terhadap pencapaian hasil pembelajaran. Adapun peranan guru Pendidikan Agama Islam dalam pelajaran toleransi dapat dilihat dari empat aspek yaitu sebagai informator, motivator, pengarah, fasilitator, dan evaluator.

\section{DAFTAR PUSTAKA}

Ashiddiq, Hasbi. (1971). Alquran dan Terjemahannya. Jakarta: Raja Fahd

Al-Munawar, Said Agil. (2003). Fiqih Hubungan Antar Sesama. Jakarta: Ciputat Press

Arfah, Sitti. (2017). Peran dan Fungsi Guru Dalam Meningkatkan Mutu Pembelajaran. Jurnal Pendidikan Islam Al-Munawwara, Vol.9(1)

Daryanto. (2008). Kamus Besar Bahasa Indonesia. Surabaya: Apollo

Denizlaiha.(2020). Peran Guru Sekolah Dasar Dalam Pembelajaran Di Era Teknologi Digital. hhtps//Jurnal. Univpgri-Palembang ac.id. diakses pada tanggal 08 April 2020

Gunawan, Fahmi. 2014. Pendidikan Karakter, Hipotesis Saphir-Whorf dan Bahasa Intelek, dan Media Sosial, dalam Jurnal Al-Ta'dib, Vol 7 (1)

Hawi, Akmal. (2013). Kompetensi Guru Pendidikan Agama Islam. Jakarta: Rajawali Pers

Kirom, Askhabul. (2017). Peran Guru dan Peserta Didik dalam Proses Pembelajaran Berbasis Multikultural. Jurnal Al-Murabbi, Vol. 3(1)

Malik, Oemar. (2009). Psikologi Belajar dan Mengajar. Bandung: Sinar Baru Algensindo

Munawir, Ahmad Warson. (2009). Kamus Arab Indonesia al-Munawir. Yogyakarta: Balai Pustaka Progresif

Nurrahmawati, Rizka. (2016). Peran Guru dalam Kegiatan Pembelajaran Bahasa Indonesia Pada Siswa Berkesulitan Belajar Spesifik III Disekolah Dasar Negeri Gadingan Kulon Progo. Jurnal Widia Ortodidaktika,Vol.5 (9)

Nurhaidah dan M. Insya Musa.(2016). Pengembangan Kompetensi Guru Terhadap Pelaksanaan Tugas Dalam Mewujudkan Tenaga Guru Yang Profesional. Jurnal Pesona Dasar, Vol.2 (4)

Munawir, Ahmad Warson. (2009). Kamus Arab Indonesia al-Munawir. Yogyakarta: Balai Pustaka Progresif

Rahman, Hibana S. (2002). Konsep Dasar Pendidikan Anak Usia Dini. Yogyakarta: PGTKI Press

Sugiyono. (2017). Metode Penelitian Kuantitatif Kualitatif dan $R \& D$. Bandung: Alfabet 